\title{
MECHANIZM PODZIELONEJ PŁATNOŚCI VAT I JEGO WPEYW NA PŁYNNOŚĆ PRZEDSIĘBIORSTWA
}

\begin{abstract}
Mechanizm Podzielonej Płatności (MPP) stanowi jeden z najważniejszych filarów systemu ograniczania wielkości luki podatkowej dot. VAT w Polsce. W przeciwieństwie do innych elementów tego systemu, takich jak Jednolity Plik Kontrolny czy raportowanie danych bankowych w ramach Systemu Transakcyjnego Izby Rozliczeniowej, MPP wywiera znaczący wpływ na płynność przedsiębiorstwa. Ewidencjonowanie środków związanych z VAT na specjalnie do tego przeznaczonych rachunkach bankowych powoduje, że płynność przedsiębiorstwa z reguły się zmniejsza; również scenariusz całkowitej utraty płynności nie jest wykluczony. Ma to miejsce w szczególności w sytuacji, w której wypływ środków związanych z VAT w ramach MPP poprzedza ich wpływ, co wykazano na przykładzie, w drodze analizy porównawczej. Funkcjonujące w literaturze przedmiotu wskaźniki płynności wydają się niewystarczające do oszacowania wpływu MPP na płynność przedsiębiorstwa, z uwagi na brak rozróżnienia rodzajowego środków a vista na rachunkach bankowych, w związku z czym zaproponowano wprowadzenie modyfikacji istniejących wskaźników. Z kolei analiza zapotrzebowania na płynność za pomocą modeli określających optymalny poziom gotówki wykazuje, w zależności od przyjętych założeń, zwiększone zapotrzebowanie na płynność lub zwiększony koszt utrzymywania dotychczasowego poziomu płynności. Na uwagę zasługują też inne koszty związane z utrzymaniem płynności w reżimie MPP, np. opłaty bankowe. Wprowadzenie MPP ma zatem, z reguły, niekorzystny wpływ na płynność finansową przedsiębiorstwa, zarówno z perspektywy zapotrzebowania na płynność, jak i bezpośrednich oraz pośrednich kosztów związanych z MPP.
\end{abstract}

Słowa kluczowe: podatki, VAT, bankowość korporacyjna, zarządzanie płynnością.

\section{WPROWADZENIE}

Podatek od towarów i usług (VAT) stanowi najważniejsze źródło dochodów budżetu państwa w Polsce. W 2017 r. kwota odnotowanych wpływów z jego tytułu wyniosła około 157 mld zł, stanowiąc aż 50\% wszystkich dochodów podatkowych oraz 45\% dochodów

\footnotetext{
${ }^{1}$ Mgr Marta Kijuk, Instytut Finansów Korporacji i Inwestycji, Kolegium Nauk o Przedsiębiorstwie, Szkoła Główna Handlowa w Warszawie, al. Niepodległości 162, 02-554 Warszawa; e-mail: marta.kijuk@doktorant.sgh.waw.pl

Marta Kijuk, MA, Institute of Corporate Finance and Investment, Collegium of Business Administration, SGH Warsaw School of Economics, al. Niepodległości 162, 02-554 Warsaw, Poland; e-mail: marta.kijuk@doktorant.sgh.waw.pl
} 
budżetu państwa ogółem² ${ }^{2}$ Kwota rzeczywiście otrzymanych wpływów (tj. VAT faktycznie pobrany) jest jednak niższa od teoretycznej kwoty, która powinna wpłynąć do budżetu przy założeniu pełnej ściągalności podatku VAT, a więc przede wszystkim przy założeniu braku oszustw podatkowych, takich jak uchylanie się od płacenia podatku czy wyłudzanie zwrotów, jak również przy braku szarej strefy. Różnicę między kwotą podatku VAT rzeczywiście otrzymaną a teoretycznie należną określa się jako lukę w VAT. Z uwagi na brak oficjalnych statystyk jest to wartość trudna do dokładnego określenia. Eksperci szacują jej poziom na około $40 \mathrm{mld} \mathrm{zł}$, przy czym już w 2017 r. dało się odnotować znaczne zmniejszenie luki (2016 r.: około 52 mld zł, 2017 r.: około $39 \mathrm{mld} \mathrm{zł})^{4}$.

W ostatnich latach do polskiego systemu prawnego wprowadzane są rozwiązania, których celem jest skuteczne zmniejszanie luki w VAT. Począwszy od lipca 2016 r., na przedsiębiorstwa stopniowo nakładane były obowiązki związane z Jednolitym Plikiem Kontrolnym. Obecnie wszyscy zarejestrowani czynni podatnicy VAT, niezależnie od skali działalności, mają obowiązek comiesięcznego dostarczania rejestru zakupu i sprzedaży VAT (czyli tak zwanego pliku JPK_VAT) do Krajowej Administracji Skarbowej (KAS) ${ }^{5}$. Dzięki temu KAS pozyskuje informacje o zakupach i sprzedaży danego przedsiębiorcy, w szczególności o numerach wystawionych i otrzymanych faktur VAT oraz ich kwotach. Przy założeniu dotychczasowej transparentności działań przedsiębiorstwa związanych z podatkiem VAT i ich zgodności z prawem, obowiązek ten nie ma bezpośredniego wpływu na płynność przedsiębiorstwa, gdyż polega on jedynie na dostarczaniu informacji. Wpływ wymogów związanych z JPK, a w szczególności z JPK_VAT, na sytuację finansową przedsiębiorstwa należy zatem rozpatrywać jedynie w obszarze kosztów, poniesionych przed przedsiębiorstwo w związku z dostosowaniem systemów informatycznych oraz procesów operacyjnych do wymogów ustawowych, jak również kosztów ponoszonych co miesiąc w związku z koniecznością przesłania JPK_VAT. Warto również podkreślić, że wymogi związane z dostarczaniem przez przedsiębiorstwo wszystkich struktur JPK nałożone zostały bezpośrednio na przedsiębiorstwo, a więc w oderwaniu od jego relacji z bankiem. To przedsiębiorstwo, a nie bank je obsługujący, ma obowiązek dostarczenia odpowiednich plików JPK - w tym również pliku z wyciągiem bankowym, czyli JPK_WB.

Kolejną istotną zmianą prawną, mającą na celu poprawę ściągalności podatku VAT i walkę z wyłudzeniami skarbowymi, było nałożenie na banki obowiązku bieżącego raportowania do KAS informacji o rachunkach bankowych przedsiębiorstw oraz o transakcjach na tych rachunkach, w ramach nowo utworzonego Systemu Teleinformatycznego Izby Rozliczeniowej ${ }^{6}$. Analiza dostarczonych danych, na podstawie odpowiednich algorytmów, ma

\footnotetext{
2 Szacunkowe dane o wykonaniu budżetu państwa za styczeń-grudzień 2017 r., Warszawa, 31.01.2018 r., https://www.mf.gov.pl/documents/764034/5924039/20180131_Szacunkowe_wykonanie_budzetu_styczen_grudzien_2017+r..pdf

${ }^{3}$ Druk nr 1864: uzasadnienie rządowego projektu ustawy o zmianie ustawy o podatku od towarów i usług oraz niektórych innych ustaw, Warszawa, 27.09.2017 r., http://www.sejm.gov.pl/ Sejm8.nsf/druk.xsp?nr=1864

${ }^{4}$ Luka VAT w Polsce w 2017 r. zmniejszy się o ok. 13 mld zt, 19 X 2017, https://www.pwc.pl/pl/ media/2017/2017-10-19-pwc-luka-vat-2017.html

${ }^{5}$ Ustawa z dnia 29 sierpnia 1997 r. Ordynacja podatkowa (tekst jedn. Dz.U. z 2017 r., poz. 201).

${ }^{6}$ Ustawa z dnia 24 listopada 2017 r. o zmianie niektórych ustaw w celu przeciwdziałania wykorzystywaniu sektora finansowego do wyłudzeń skarbowych (Dz.U. z 2017 r., poz. 2491) (dalej jako ustawa STIR).
} 
pozwolić KAS na zidentyfikowanie znamion typowych dla wyłudzeń VAT, np. symptomów „znikających podatników” w ramach karuzel VAT. Szef KAS ma prawo zablokowania podejrzewanego rachunku na 72 godziny, z możliwością przedłużenia blokady nawet do 3 miesięcy, tak aby chronić środki należne skarbowi państwa przed zniknięciem z systemu finansowego. Obowiązki związane ze STIR są zatem nałożone przede wszystkim na banki, jednak przedsiębiorca może odczuć bezpośredni skutek tej ustawy właśnie w postaci blokady środków na jego rachunku bankowym. Przy założeniu dotychczasowej transparentności działań przedsiębiorstwa związanych z podatkiem VAT i ich zgodności z prawem, obowiązek ten prawdopodobnie nie będzie miał bezpośredniego wpływu na płynność przedsiębiorstwa, jednak nie można z całą pewnością wykluczyć ryzyka blokady rachunku bankowego nawet przy takim założeniu. Z tego względu wpływ ustawy STIR na płynność przedsiębiorstwa można określić jako „,mało prawdopodobny, lecz całkowity”: do blokady rachunku prawdopodobnie nie dojdzie, lecz jeśli już taki negatywny dla przedsiębiorstwa scenariusz się zrealizuje, wówczas przedsiębiorstwo może zostać całkowicie pozbawione możliwości wywiązania się $\mathrm{w}$ terminie $\mathrm{z}$ najbardziej wymagalnych zobowiązań, a więc może utracić płynność finansową.

Najistotniejszą jednak zmianą prawną mającą na celu uszczelnienie polskiego systemu VAT jest Mechanizm Podzielonej Płatności (MPP, ang. Split Payment Mechanism), który wszedł w życie 1 lipca 2018 r. Na mocy znowelizowanych przepisów Prawa bankowego ${ }^{7}$, banki mają obowiązek otworzyć i prowadzić specjalny rachunek VAT dla każdego przedsiębiorcy (posiadacza rachunku rozliczeniowego). Znowelizowana tym samym aktem prawnym ustawa o VAT wprowadziła z kolei nowy rodzaj komunikatu przelewu - tak zwaną podzieloną płatność (przelew MPP). Przedsiębiorca, który płaci kontrahentowi za fakturę VAT, może dokonać zapłaty kwoty brutto faktury w tradycyjny sposób (czyli na przykład przelewem Elixir, Express Elixir czy Sorbnet), jednak ma również możliwość skorzystania z nowego rodzaju przelewu - przelewu MPP. Decydując się na zlecenie przelewu MPP, przedsiębiorca podaje w ustrukturyzowany sposób szczegółowe informacje dotyczące tej płatności (kwotę brutto, kwotę VAT, numer faktury, NIP odbiorcy). Bank realizujący taki przelew pobiera kwotę VAT z rachunku VAT swojego klienta, przeksięgowując ją na rachunek bieżący tegoż przedsiębiorcy, a następnie komunikatem przelewu MPP wysyła całą kwotę brutto do banku odbiorcy. Bank odbiorcy, otrzymawszy przelew MPP, ma obowiązek nie tylko zaksięgować wskazaną kwotę brutto na rachunku bieżącym swojego klienta, ale ma też obowiązek przeksięgować wskazaną kwotę VAT na rachunek VAT swojego klienta. Tym samym Ustawa MPP tworzy swoisty „ekosystem VAT” - system rachunków VAT, funkcjonujący niejako równolegle do systemu rachunków rozliczeniowych przedsiębiorców. Mimo że posiadaczem rachunku VAT jest przedsiębiorca (a nie bank, Ministerstwo Finansów czy KAS), to dostęp do środków zgromadzonych na rachunkach VAT jest jednak dla przedsiębiorcy istotnie ograniczony. Ustawa MPP precyzuje zamknięty katalog dopuszczalnych uznań i obciążeń rachunku VAT, a czynności te wykonywane są przez banki niejako w tle zasadniczych rozliczeń. O ile więc zlecanie przelewów do kontrahentów jako MPP jest dla przedsiębiorcy dobrowolne, o tyle otrzymanie przelewu MPP od kontrahenta oznacza obowiązkowe przekazanie wskazanej kwoty VAT na rachunek VAT. Tak zbudowany mechanizm pozwala zakładać, że wpływ Ustawy MPP na płynność przedsiębiorstwa można określić jako „,częściowy, lecz niemal pewny”: wbudowany

\footnotetext{
${ }^{7}$ Ustawa z dnia 15 grudnia 2017 r. o zmianie ustawy o podatku od towarów i usług oraz niektórych innych ustaw (Dz.U. z 2018 r., poz. 62).
} 
w MPP mechanizm „kuli śniegowej”, obejmujący swym zakresem coraz szersze kręgi uczestników systemu rozliczeń między przedsiębiorstwami, pozwala przypuszczać, że dane przedsiębiorstwo najprawdopodobniej zostanie dotknięte MPP, a więc otrzyma płatność, z której część kwoty zostanie przez bank przekazana na rachunek VAT, tym samym ,zamrażając" tę kwotę do wykorzystania tylko na cele podatku VAT. W skrajnym przypadku, $19 \%$ bieżącej płynności przedsiębiorstwa $(0,23 \times 1,23)$ może zostać zamrożone na rachunku VAT.

Podsumowanie wybranych, omówionych powyżej, zmian prawnych mających na celu zmniejszenie luki w VAT, przedstawia tabela 1.

Tabela 1. Zestawienie wybranych zmian prawnych dotyczących ograniczania wielkości luki w VAT

\begin{tabular}{|c|c|c|c|c|}
\hline Lp. & $\begin{array}{c}\text { Zmiana } \\
\text { prawna }\end{array}$ & $\begin{array}{c}\text { Główny adresat } \\
\text { zmiany }\end{array}$ & $\begin{array}{c}\text { Prawdopodobieństwo } \\
\text { wpływu na płynność }\end{array}$ & $\begin{array}{c}\text { Konsekwencje wpływu } \\
\text { na płynność }\end{array}$ \\
\hline 1 & JPK & przedsiębiorca & brak & nie dotyczy \\
\hline 2 & STIR & bank & niskie & bardzo wysokie \\
\hline 3 & MPP & przedsiębiorca i bank & bardzo wysokie & częściowe \\
\hline
\end{tabular}

Źródło: opracowanie własne.

Wszystkie omawiane wyżej zmiany prawne są wobec siebie komplementarne z perspektywy celu fiskalnego przyświecającego ich wdrożeniu. Z perspektywy przedsiębiorstwa natomiast, ryzyko wpływu na płynność przedsiębiorstwa (szacowane jako funkcja danego zdarzenia, prawdopodobieństwo zajścia danego zdarzenia oraz konsekwencji jego zajścia) ${ }^{8}$ jest największe w przypadku regulacji MPP.

Celem niniejszego artykułu jest dokonanie analizy wpływu regulacji MPP na poziom dostępnych płynnych środków finansowych przedsiębiorstwa na jego rachunkach bankowych, jak również wykazanie, że wpływ ten jest co do zasady negatywny, choć nie jest on widoczny w klasycznej analizie wskaźnikowej sprawozdań finansowych w zakresie wskaźników płynności. Ponadto MPP powoduje trudności w oszacowaniu optymalnego poziomu gotówki, która winna być utrzymywana przez przedsiębiorstwo na rachunkach bankowych, co również zostanie wykazane w dalszej części artykułu.

\section{WPŁYW MPP NA POZIOM DOSTĘPNYCH PŁYNNYCH ŚRODKÓW FINANSOWYCH}

Środki zgromadzone przez przedsiębiorstwo na bankowych rachunkach rozliczeniowych (bieżących i pomocniczych) stanowią - obok gotówki w kasie - najbardziej płynne zasoby pieniężne przedsiębiorstwa ${ }^{9}$. Środki te mogą być wykorzystane praktycznie w każdym momencie do zrealizowania bieżących zobowiązań przedsiębiorstwa, a ograniczenie dysponowania tymi środkami następuje wskutek decyzji samego przedsiębiorstwa (na przykład założenie lokaty) albo wskutek działań zewnętrznych, które z reguły wynikają z faktu

\footnotetext{
8 T. Aven, Quantitative Risk Assessment. The Scientific Platform, New York 2011, s. 17-20.
}

${ }^{9}$ W. Bień, Zarzadzanie finansami przedsiębiorstwa, Warszawa 2011, s. 212-216. 
nieprzestrzegania przez przedsiębiorstwo określonych zasad (na przykład wspomniana wyżej blokada rachunku z powodu podejrzanych transakcji na podstawie ustawy STIR).

W przypadku rozliczeń z kontrahentami, swobodne dysponowanie środkami zgromadzonymi na rachunku bankowym oznacza, że środki te nie są oznaczone co do rodzaju, a więc np. cała kwota brutto wpłacona przez kontrahenta (składająca się z kwoty netto oraz kwoty VAT, która docelowo - pośrednio - powinna trafić do urzędu skarbowego) może być przeznaczona na wydatki przedsiębiorstwa niezwiązane z VAT, a więc na przykład na pensje pracowników. Oznacza to, że władze skarbowe wyrażają swoiste zaufanie wobec podatnika, że kwota VAT - choć chwilowo wydana na cele niezwiązane z VAT - docelowo zostanie odzyskana przez urząd skarbowy, być może z innych, niezwiązanych z podatkiem VAT źródeł.

Wątpliwości związane z zasadnością tego zaufania leżą u podstaw Mechanizmu Podzielonej Płatności. Zgodnie z logiką MPP, kwota VAT z faktury opłaconej przelewem MPP trafia na specjalnie wydzielony rachunek VAT. Stąd może być ona wykorzystana jedynie na cele związane z VAT, których zamknięty katalog wskazuje ustawa MPP. Oznacza to, w pewnym uproszczeniu, że środki będące w dyspozycji przedsiębiorstwa na jego rachunku VAT mogą być wykorzystane jedynie do zapłaty kwoty VAT wykazanej na fakturze wystawionej przez kontrahenta, lub do zapłaty podatku VAT do urzędu skarbowego. Tym samym trudno jest określić te środki jako w pełni płynne.

Dla analizy dostępności płynnych środków finansowych w systemie MPP kluczowa jest ponadto logika księgowań przelewów MPP, realizowana przez bank. Rachunek VAT nie może wykazywać salda ujemnego. Jeśli podatnik nie dysponuje wystarczającym saldem rachunku VAT, może on jednak nadal zrealizować przelew MPP - brakująca kwota VAT zostanie wówczas uzupełniona z jego rachunku rozliczeniowego, a kontrahent otrzyma na rachunek VAT całość przelanej kwoty VAT. Oznacza to, że w takim scenariuszu przedsiębiorca-płatnik zasilił ów „ekosystem VAT” określoną kwotą wprost z rachunku bieżącego. Jeśli jednak podatnik ów otrzyma następnie przelew MPP od swojego kontrahenta, cała kwota VAT również zostanie odprowadzona na rachunek VAT. Banki nie analizują, czy miało miejsce uprzednie ,zasilenie ekosystemu VAT” na kwotę np. 1000 zł po to, aby z otrzymanego przelewu MPP na kwotę 123000 zł, w tym 23000 zł VAT odprowadzić na rachunek VAT tylko 22000 zł. Technika księgowań jest niezależna od uprzednich zdarzeń: cała wskazana kwota VAT z przelewu przychodzącego MPP trafia na rachunek VAT odbiorcy przelewu. Oznacza to w szczególności, że obniżenie dostępnych płynnych środków finansowych odczuwają przedsiębiorstwa, których rozkład wpływów i wydatków w czasie jest ukształtowany w ten sposób, że najpierw następują wpływy niezwiązane z VAT a wypływy związane z VAT (tj. zasilanie ,ekosystemu VAT”), a z biegiem czasu przybywa wpływów związanych z VAT oraz wypływów niezwiązanych z VAT (tj. mrożenie środków z VAT).

Mechanizm mrożenia środków z VAT przy niekorzystnym rozkładzie czasowym rozliczeń można prześledzić na przykładzie. Przy założeniu braku systemu MPP, rozliczenia przykładowego przedsiębiorstwa przedstawia tabela 2 . W przedstawionym przykładzie przedsiębiorstwo nie ma problemów z realizacją bieżących zobowiązań, a saldo rachunku bieżącego jest zawsze dodatnie. 
Tabela 2. Dostępne płynne środki finansowe w wariancie bez MPP (przykład)

\begin{tabular}{|c|c|c|c|c|c|}
\hline Lp. & $\begin{array}{c}\text { Wpłaty } \\
\text { od konsumentów }\end{array}$ & $\begin{array}{c}\text { Wpłaty } \\
\text { od przedsiębiorstw }\end{array}$ & $\begin{array}{c}\text { Zapłata } \\
\text { przedsiębiorstwom }\end{array}$ & $\begin{array}{c}\text { Zapłata } \\
\text { pensji }\end{array}$ & $\begin{array}{c}\text { Saldo } \\
\text { rachunku } \\
\text { bieżącego }\end{array}$ \\
\hline 1 & 2460 & & & & $\mathbf{2 4 6 0}$ \\
\hline 2 & & & -1845 & & $\mathbf{6 1 5}$ \\
\hline 3 & 1230 & & & & $\mathbf{1 8 4 5}$ \\
\hline 4 & & & -1476 & & $\mathbf{3 6 9}$ \\
\hline 5 & & 2460 & & -2500 & $\mathbf{2 8 2 9}$ \\
\hline 6 & & & & & $\mathbf{5 2 4 9}$ \\
\hline 7 & & 4920 & & -5000 & $\mathbf{2 4 9}$ \\
\hline 8 & & & & & \\
\hline
\end{tabular}

Źródło: opracowanie własne.

Wprowadzenie MPP powoduje, że rozliczenia związane z VAT między przedsiębiorstwami wykonywane są z wykorzystaniem środków na rachunku VAT - o ile są one dostępne. Jak wykazano w dalszej części przykładu, w tabeli 3, przy analogicznych wpływach i wydatkach przedsiębiorstwo objęte MPP zaczyna mieć kłopoty z płynnością: saldo rachunku bieżącego przyjmuje wartości ujemne, mimo że łączna kwota środków do dyspozycji (saldo ogółem) pozostaje bez zmian.

Tabela 3. Dostępne płynne środki finansowe w wariancie z MPP (przykład - cd.)

\begin{tabular}{|c|c|c|c|c|c|c|c|}
\hline Lp. & $\begin{array}{c}\text { Wpłaty od } \\
\text { konsumentów }\end{array}$ & $\begin{array}{c}\text { Wpłaty od } \\
\text { przedsiębiorstw }\end{array}$ & $\begin{array}{c}\text { Zapłata } \\
\text { przedsię- } \\
\text { biorstwom }\end{array}$ & $\begin{array}{c}\text { Zapłata } \\
\text { pensji }\end{array}$ & $\begin{array}{c}\text { Saldo } \\
\text { rachunku } \\
\text { bieżącego }\end{array}$ & $\begin{array}{c}\text { Saldo } \\
\text { rachunku } \\
\text { VAT }\end{array}$ & $\begin{array}{c}\text { Saldo } \\
\text { ogółem }\end{array}$ \\
\hline 1 & 2460 & & & & 2460 & 0 & $\mathbf{2 4 6 0}$ \\
\hline 2 & & & -1500 & & 615 & 0 & $\mathbf{6 1 5}$ \\
\hline 3 & 1230 & & & & 1845 & 0 & $\mathbf{1 8 4 5}$ \\
\hline 4 & & & -1200 & & 369 & 0 & $\mathbf{3 6 9}$ \\
\hline 5 & & -276 VAT & & & 2369 & 460 & $\mathbf{2 8 2 9}$ \\
\hline 6 & & & & -2500 & $-\mathbf{1 3 1}$ & 460 & $\mathbf{3 2 9}$ \\
\hline 7 & & 4000 & & & 3869 & 1380 & $\mathbf{5 2 4 9}$ \\
\hline 8 & & & & -5000 & -1131 & 1380 & $\mathbf{2 4 9}$ \\
\hline
\end{tabular}

Źródło: opracowanie własne. 
Analizowany przykład opisuje jeden z możliwych scenariuszy. W odwrotnej sytuacji (gdy wpływy związane z VAT poprzedzą wydatki związane z VAT) wpływ MPP może być dla przedsiębiorstwa neutralny, a w szczególnych przypadkach (gdy przedsiębiorstwo skorzysta z przyspieszonego zwrotu VAT na rachunek VAT) może on mieć nawet pozytywny skutek w zakresie płynności. Niemniej jednak, co do zasady, MPP zmniejsza zasób środków finansowych dostępnych do swobodnej dyspozycji przedsiębiorstwa, czyli ogranicza jego płynność, wpływając negatywnie na inne obszary działalności przedsiębiorstwa. Gdy zrealizuje się ów negatywny scenariusz, odzyskanie i utrzymanie płynności staje się niezbędne w procesie naprawy przedsiębiorstwa. Płynność staje się wówczas szczególnym zasobem, bowiem jej źródła występują zawsze poza przedsiębiorstwem i kształtowane są przez szereg zewnętrznych czynników ${ }^{10}$. W zmienionym przez MPP otoczeniu biznesowym i prawnym konieczną zatem wydaje się dogłębna analiza strumieni finansowych przedsiębiorstwa i podjęcie odpowiednich działań (na przykład ustaleń z kontrahentami), tak by odpowiednio wcześnie dostosować przedsiębiorstwo do nowych wyzwań związanych z płynnością. Sytuacja taka oznacza konieczność zmiany tak zwanych rutyn, o których mowa w ewolucyjnej teorii przedsiębiorstwa ${ }^{11}$. Może to jednak stanowić duże wyzwanie w związku z inercją, towarzyszącą zazwyczaj wprowadzaniu zmian w przedsiębiorstwie ${ }^{12}$.

\section{MPP A WSKAŹNIKI PŁYNNOŚCI W ANALIZIE SPRAWOZDAŃ FINANSOWYCH}

Płynność przedsiębiorstwa nie jest bezwzględną, mierzalną wartością wykazywaną bezpośrednio w sprawozdaniach finansowych. Płynność rozumiana jest najczęściej jako zdolność do regulowania zobowiązań przedsiębiorstwa ${ }^{13}$ lub też jako zdolność do uzyskania gotówki w razie potrzeby ${ }^{14}$, choć te krótkie definicje nie wyczerpują w pełni jej znamion.

Jak wykazano powyżej, MPP pogarsza w praktyce płynność przedsiębiorstwa. Powstaje więc pytanie, czy istnieją aspekty owego - zazwyczaj negatywnego - wpływu MPP na płynność, które można wyczytać bezpośrednio ze sprawozdań finansowych, oraz czy sam wpływ można pośrednio skwantyfikować, a więc wyliczyć go jako wskaźnik wynikający $\mathrm{z}$ danych zawartych w tych właśnie dokumentach.

Przede wszystkim warto zaznaczyć, że rachunek VAT - mimo ograniczeń w dysponowaniu środkami na nim zgromadzonymi - prowadzony jest na analogicznych zasadach, jak rachunek rozliczeniowy przedsiębiorstwa. Właścicielem środków zgromadzonych na rachunku (czyli podmiotem, wobec którego bank ma zobowiązanie do zwrotu tychże środków) jest przedsiębiorstwo. Jeśli zatem analizie w ramach bilansu przedsiębiorstwa podlega pozycja „środki pieniężne w kasie i na rachunkach” - będą tam wykazane zarówno w pełni płynne środki pieniężne na rachunku rozliczeniowym, jak i teoretycznie równie płynne

${ }^{10}$ P. Masiukiewicz, Udziat banków w tworzeniu drugiej szansy dla przedsiębiorstw [w:] A. Szelągowska (red.), Wspótczesna bankowość korporacyjna, CeDeWu, Warszawa 2011, s. 129.

11 A. Noga, Teorie przedsiębiorstw, PWE, Warszawa 2010, s. 179.

12 D.A. Endovitsky i in., Changes and Inertia-Analysis and Forecast of Functional Interconnections [w:] D.A. Endovitsky, E.G. Popkova (red.), Management of Changes in Socio-Economic Systems, Springer, Cham 2018, s. 18.

${ }^{13}$ M. Bojańczyk, Finanse przedsiębiorstwa, Oficyna Wydawnicza SGH, Warszawa 2012, s. 203.

${ }^{14}$ G. Adalsteinsson, The Liquidity Risk Management Guide. From Policy to Pitfalls, Wiley, Chichester 2014, s. 23-35. 
środki na rachunkach VAT, które cechują się jednak ograniczeniami w zakresie płynności. Co ciekawe, środki zgromadzone na rachunku VAT również, co do zasady, mają charakter wkładu a vista - co oznacza, że przedsiębiorstwo może w każdej chwili dokonać tymi środkami zapłaty kwoty podatku VAT wykazanej na fakturze wystawionej przez kontrahenta lub podatku VAT do urzędu skarbowego. W tym przypadku jednak pojawiają się ograniczenia rodzajowe. Zagadnienie płynności przedsiębiorstwa nabiera więc dodatkowego wymiaru, gdyż teoretycznie najpłynniejsze środki (według kryterium czasu) stają się w praktyce w większości przypadków środkami najmniej płynnymi (co oznacza, że trudno jest je upłynnić, na przykład w celu wypłaty pensji pracownikom czy zapłaty podatku CIT).

Powstaje więc kolejne pytanie: czy wpływ regulacji MPP można zatem wyczytać z analizy wskaźnikowej. Analiza wskaźnikowa polega na obliczeniu relacji między wielkościami występującymi w sprawozdaniach finansowych. Tak wyliczony wskaźnik wymaga interpretacji - sama wartość bezwzględna relacji między poszczególnymi elementami informacji finansowej nie jest zbyt użyteczna, a miarodajność tak otrzymanych wskaźników zależy przede wszystkim od jakości danych wsadowych ${ }^{15}$.

Do najpopularniejszych wskaźników płynności przedsiębiorstwa należą ${ }^{16}$ :

- wskaźnik płynności bieżącej (current ratio, W1), określający stopień pokrycia bieżących zobowiązań środkami obrotowymi:

$$
W 1=\frac{\text { majątek obrotowy }}{\text { zobowiązania bieżące }}
$$

- wskaźnik szybkości spłaty zobowiązań (quick ratio, W2), pokazujący zdolność przedsiębiorstwa do szybkiego uregulowania krótkoterminowych zobowiązań:

$$
W 2=\frac{\text { płynne środki obrotowe }}{\text { zobowiązania bieżące }}=\frac{\text { majątek obrotowy }- \text { zapasy }}{\text { zobowiązania bieżące }}
$$

- wskaźnik płynności natychmiastowej (cash ratio, W3), pokazujący zdolność przedsiębiorstwa do pokrycia bieżących zobowiązań z posiadanych środków pieniężnych:

$$
W 3=\frac{\text { bieżące środki pieniężne }}{\text { zobowiązania bieżące }}=\frac{\text { majątek obrotowy }- \text { zapasy }- \text { należności }}{\text { zobowiązania bieżące }}
$$

Nie istnieją optymalne, uniwersalne wartości powyższych wskaźników. Przykładowo, wskaźnik $W 1$ dla huty stali jest zazwyczaj wysoki, ale rynek akceptuje niższą wartość tego wskaźnika dla detalistów ${ }^{17}$. Im wyższa jest wartość danego wskaźnika, tym wyższa płynność przedsiębiorstwa.

Poszczególne wskaźniki ( $W 1, W 2, W 3)$ powstawały poprzez stopniowe odejmowanie od wartości majątku obrotowego przedsiębiorstwa wartości najmniej płynnych aktywów:

${ }^{15}$ M. Bojańczyk, Finanse przedsiębiorstwa..., s. 203.

${ }^{16}$ W. Bień, Zarzadzanie finansami przedsiębiorstwa..., s. 99; A. Motylska-Kuźma, J. Wieprow, Decyzje finansowe w przedsiębiorstwie. Problemy i zadania, Difin, Warszawa 2013, s. 42-44.

17 E.C. Buljevich, Y.S. Park, Project Financing and the International Financial Markets, Springer, Berlin 2009, s. 134. 
najpierw zapasów, później również należności. W każdym jednak wariancie do posiadanych środków pieniężnych zaliczać się będą wszystkie środki zgromadzone na rachunkach bankowych, w tym również środki zgromadzone na rachunkach VAT. Oznacza to, że powszechnie stosowane wskaźniki płynności nie pozwolą na oszacowanie wpływu MPP na płynność.

Być może rozwiązaniem mogłoby być wprowadzenie nowego wskaźnika płynności na przykład wskaźnika uniwersalnej płynności bieżącej (all-purpose cash ratio, W4) o następującej konstrukcji:

$$
\begin{aligned}
W 4 & =\frac{\text { bieżące uniwersalne środki pieniężne }}{\text { zobowiązania bieżące }}= \\
& =\frac{\text { majątek obrotowy }- \text { zapasy }- \text { należności }- \text { aktywa celowościowe }}{\text { zobowiązania bieżące }}
\end{aligned}
$$

gdzie jako „aktywa celowościowe” rozumie się krótkoterminowe aktywa finansowe, które teoretycznie zachowują płynność, ale są przeznaczone tylko do realizacji określonych transakcji, co oznacza, że mimo teoretycznej płynności nie mogą być wykorzystane do pokrycia zobowiązań bieżących. W szczególności można przyjąć, że jako aktywa celowościowe ujmuje się jedynie środki zgromadzone przez przedsiębiorstwo na rachunku VAT.

W bardziej skomplikowanej wersji tego wskaźnika można także rozważyć wyłączenie z zobowiązań bieżących tych zobowiązań, do realizacji których przeznaczone są aktywa celowościowe, a więc na przykład kwotę podatku VAT, tworząc zmodyfikowany wskaźnik uniwersalnej płynności bieżącej (adjusted all-purpose cash ratio, W5) o następującej konstrukcji:

$$
\begin{aligned}
W 5 & =\frac{\text { bieżące uniwersalne środki pieniężne }}{\text { uniwersalne zobowiązania bieżące }}= \\
& =\frac{\text { majątek obrotowy }- \text { zapasy }- \text { należności }- \text { aktywa celowościowe }}{\text { zobowiązania bieżące }- \text { zobowiązania celowościowe }}
\end{aligned}
$$

W szczególności, porównanie wartości wskaźników W3 i W5 pozwoliłoby na oszacowanie wpływu wprowadzenia pewnych „oznaczonych rodzajowo” środków do realizacji „oznaczonych rodzajowo” zobowiązań. Z kolei wyliczenie relacji krótkoterminowych aktywów celowościowych do odpowiadających im merytorycznie bieżących zobowiązań celowościowych pozwoliłoby na oszacowanie płynności w ramach danej, specyficznej rodzajowo, grupy aktywów oraz odpowiadających im zobowiązań krótkoterminowych.

\section{SZACOWANIE OPTYMALNEGO POZIOMU GOTÓWKI Z UWZGLĘDNIENIEM MPP}

Zapewnienie płynności w przedsiębiorstwie jest jednym z kluczowych zadań kadry zarządzającej jego finansami. Brak możliwości terminowego realizowania bieżących zobowiązań, utrzymujący się przez dłuższy czas, może prowadzić do kryzysu, a docelowo nawet do upadłości. Nie oznacza to jednak, że należy maksymalizować zasoby płynnych środków 
przedsiębiorstwa. Utrzymanie płynności kosztuje, dlatego należy znaleźć złoty środek pomiędzy ryzykownym brakiem płynności a kosztowną nadpłynnością. Określenie i utrzymywanie odpowiedniego poziomu gotówki należy do kluczowego obszaru decyzji, podejmowanych przez kadrę zarządzającą przedsiębiorstwa w perspektywie długoterminowej ${ }^{18}$.

W teorii i praktyce finansów stosowanych jest wiele modeli, pozwalających na oszacowanie optymalnego poziomu najpłynniejszych środków finansowych. Modele te stosowane są przy różnych - mniej lub bardziej restrykcyjnych - założeniach.

Jednym z prostszych modeli, opartym na założeniu o stałości wydatków, ich pewności i równomiernym rozłożeniu w czasie, jest model Baumola. Optymalny stan gotówki $\left(\mathrm{C}_{\mathrm{opt}}\right)$ określany jest w tym modelu w następujący sposób ${ }^{19}$ :

$$
C_{\text {opt }}=\sqrt{\frac{\text { całkowite zapotrzebowanie na gotówkę } \times \text { stały koszt transferu }}{2 \times \text { koszt alternatywny utrzymywania gotówki }}}
$$

Przykładowo, jeśli przedsiębiorstwo w ciągu roku ma zapotrzebowanie na gotówkę w łącznej kwocie 1000000 zł, każdorazowa transakcja zamiany papierów wartościowych na gotówkę (i na odwrót) generuje stały koszt w kwocie 200 zł, a stopa oprocentowania bonów skarbowych wynosi $1 \%$ w skali roku, to optymalny poziom gotówki:

$$
C_{o p t}=\sqrt{\frac{1000000 \times 200}{2 \times 0,01}}=100000 \mathrm{zl}
$$

Przedsiębiorstwo powinno więc dysponować płynną kwotą 100000 zł, przeznaczoną na realizację bieżących zobowiązań.

Wprowadzenie MPP do modelu Baumola nie będzie miało wpływu ani na stały koszt transferu, ani na alternatywny koszt utrzymywania płynnych środków - są to bowiem wartości dyktowane przez rynek, przedsiębiorstwo jest tu cenobiorcą. Pozostaje jednak pytanie o całkowite zapotrzebowanie na płynne środki pieniężne, a zatem w jaki sposób należałoby oszacować wpływ regulacji MPP na tę wielkość.

Istnieją dwa możliwe podejścia w tym zakresie:

1. Po pierwsze: możliwe jest założenie, że po wprowadzeniu MPP zapotrzebowanie na płynne środki nadal pozostaje jednorodne, co jest tożsame ze stwierdzeniem, że środki pieniężne nie są oznaczone co do rodzaju. W takiej sytuacji, w analizowanym przykładzie, wartość $\mathrm{C}_{\text {opt }}$ pozostanie na dotychczasowym poziomie $100000 \mathrm{zł}$. Nie oznacza to jednak, że sytuacja w zakresie płynności przedsiębiorstwa pozostała bez zmian: aby uzyskać płynne środki w kwocie 100000 zł, przedsiębiorstwo musi zrezygnować z części bardziej opłacalnych inwestycji, np. w papiery wartościowe, w wysokości kwoty zgromadzonej na rachunku VAT. Przykładowo, jeśli z utrzymywanych uprzednio $100000 \mathrm{zł}$ po wprowadzeniu MPP na rachunku VAT znajdzie się kwota $15000 \mathrm{zł}$, to na rachunku bieżącym, do swobodnej dyspozycji przedsiębiorstwa, pozostanie już zaledwie $85000 \mathrm{zł}$. Brakujące $15000 \mathrm{zł}$ w pełni płynnych środków przedsiębiorstwo musi zapewnić, upłynniając część dotychczasowych inwestycji, a więc ponosząc dodatkowe koszty płynności;

\footnotetext{
${ }^{18}$ K. Prędkiewicz, R. Golej, Zarządzanie finansami przedsiębiorstwa, Marina, Wrocław 2015, s. 13.
}

19 A. Motylska-Kuźma, J. Wieprow Decyzje finansowe w przedsiębiorstwie..., s. 110. 
2. Po drugie: możliwe jest założenie, że po wprowadzeniu MPP zapotrzebowanie na płynne środki staje się różnorodne, co jest tożsame ze stwierdzeniem, że środki pieniężne są oznaczone co do rodzaju. W takiej sytuacji, w analizowanym przykładzie, należy wyliczyć osobno zapotrzebowanie na środki w pełni płynne, a osobno na środki ,,celowościowo płynne”, czyli przeznaczone do zapłaty podatku VAT. Zakładając, że z owego 1000000 zł kwota wynikająca z potrzeb poza VAT wynosi 900000 zł, a kwota przeznaczona na VAT wynosi 100000 zł, można wyliczyć dwie wartości optymalnego stanu gotówki. Dla kwot poza VAT wartość ta wynosi:

$$
C_{o p t}=\sqrt{\frac{900000 \times 200}{2 \times 0,01}}=94868,33 \mathrm{zł}
$$

a dla kwot związanych z VAT:

$$
C_{o p t}=\sqrt{\frac{100000 \times 200}{2 \times 0,01}}=31622,78 \mathrm{zł}
$$

Suma tych wartości wynosi 122 491,11 zł, a więc jest wyższa od szacowanego alternatywnie poziomu 100000 zł. Wynika to ze zwiększonych kosztów transferu, które są skutkiem konieczności równoległego utrzymywania płynności w dwóch niezależnych strumieniach.

Model Baumola jest jednym z najprostszych modeli służących szacowaniu optymalnego poziomu gotówki. Istnieją inne modele, oparte na nieco bardziej realistycznych założeniach (np. na losowości wpływów i wydatków), takie jak np. model Millera-Orra ${ }^{20}$. Niezależnie jednak od przyjętej metodologii i zastosowanego modelu, wprowadzenie MPP spowoduje wzrost kosztów utrzymania optymalnej płynności w przedsiębiorstwie - czy to wskutek zwiększenia wartości utrzymywanej kwoty, czy poprzez koszty alternatywne mrożenia środków na rachunkach VAT.

\section{PODSUMOWANIE}

Mechanizm Podzielonej Płatności, z uwagi na przyświecający mu cel fiskalny, bywa najczęściej oceniany z perspektywy makroekonomicznej. Rachunki VAT, prowadzone przez banki na rzecz przedsiębiorców, tworzą nowy, celowościowy system rozliczeń, funkcjonujący równolegle z tradycyjnym systemem bankowym, w ramach którego posiadacz rachunku może swobodnie dysponować zgromadzonymi przez siebie środkami pieniężnymi. System ten jest teoretycznie dobrowolny, jednak Ustawa MPP przewiduje szereg zachęt, które mają skłonić przedsiębiorców do korzystania z tego systemu. Wśród zachęt wskazanych w Ustawie MPP znajduje się, przykładowo, zapis o zwolnieniu przedsiębiorcy z solidarnej odpowiedzialności za VAT w sytuacji, gdy do zapłaty swojemu kontrahentowi wykorzysta przelew MPP. W sytuacji otrzymania takiego przelewu, kontrahent będzie mógł swobodnie dysponować jedynie kwotą netto, natomiast kwota VAT zostanie „oznaczona

${ }^{20}$ CIMA Study Text. Operational Paper F1. Financial Reporting and Taxation for Exam in 2017, BPP Learning Media, London 2016, s. 448-450. 
co do rodzaju" i będzie przeznaczona tylko do obrotu związanego z podatkiem VAT. Decyzja o zastosowaniu - lub nie - Mechanizmu Podzielonej Płatności leży zatem po stronie płatnika. Przedsiębiorca otrzymujący przelew nie ma w tym przypadku prawa do decyzji o sposobie zapłaty, czy też prawa odmowy przyjęcia przelewu MPP. Jest to ciekawa konstrukcja z punktu widzenia chociażby Kodeksu cywilnego, gdyż zgodnie z jego przepisami, co do zasady dłużnik może zwolnić się od zobowiązania także poprzez spełnienie innego świadczenia niż to, które wynika $\mathrm{z}$ treści samego zobowiązania; jeśli jednak przedmiot świadczenia miałby być zmieniony, to stać się to może jedynie za zgodą wierzyciela ${ }^{21}$. Trudno rozstrzygnąć kwestię, czy spełnienie zobowiązania (tj. zapłaty faktury VAT) z wykorzystaniem przelewu MPP, a więc w sposób mniej korzystny dla wierzyciela, jest już spełnieniem ,innego świadczenia”, o którym mowa w przywołanym przepisie. Jest to również świadczenie pieniężne, jednak specyficzne - z pewnością inne niż tradycyjnie wykorzystywane przelewy bankowe.

W analizie wpływu MPP na płynność przedsiębiorstwa - a więc w analizach sprawozdań finansowych, wskaźników finansowych oraz optymalnego poziomu gotówki, omówionych pokrótce w poszczególnych rozdziałach niniejszego artykułu - na pierwszy plan wysuwają się dwie zasadnicze kwestie.

Pierwszą z nich jest zagadnienie braku oznaczenia, co do rodzaju, środków pieniężnych przedsiębiorstwa, utrzymywanych na rachunkach bankowych. W istniejących klasyfikacjach czy wskaźnikach finansowych wszelkie środki a vista traktowane są tak samo: jako najbardziej płynne aktywa przedsiębiorstwa. Analiza MPP pokazuje, że szybkość dostępu do środków nie zawsze oznacza ich najwyższą płynność, a w systematyce krótkoterminowych środków pieniężnych i innych aktywów pieniężnych pojawia się potrzeba oznaczania środków co do ich rodzaju. Sposób spełnienia świadczenia przez dłużnika (a więc podjęcie przez niego decyzji, czy zapłaci za fakturę zwykłym przelewem, czy przelewem MPP) może mieć bardzo różny wpływ na płynność przedsiębiorstwa: środki mogą być do dyspozycji przedsiębiorstwa w pełnej kwocie od razu, lub - w skrajnym przypadku - przedsiębiorstwo musi czekać do 60 dni na to, aż - na wniosek przedsiębiorstwa - naczelnik urzędu skarbowego wyrazi zgodę na przeksięgowanie kwoty VAT z rachunku VAT na rachunek bieżący. Tymczasem, formalnie, w obu przypadkach są to - teoretycznie takie same środki $a$ vista.

Drugą ważną kwestią jest zagadnienie kosztów związanych z utrzymaniem płynności. Jak wykazano w rozdziale 3. niniejszego artykułu, MPP zwiększa koszty utrzymywania płynności, gdyż optymalny poziom gotówki w wariancie uwzględniającym MPP wyznaczony jest na wyższym poziomie niż analogiczna wartość w systemie tradycyjnych rozliczeń (ceteris paribus). Nie są to jednak jedyne koszty związane z utrzymaniem płynności. Warto zauważyć, że przedsiębiorstwo rozsądnie dysponujące środkami finansowymi będzie starało się samo realizować (zlecać) przelewy MPP gdy tylko będzie to możliwe. Jeśli bowiem faktura na kwotę, przykładowo, 123 zł (w tym 23 zł VAT) wymaga zapłaty, a przedsiębiorstwo posiada środki zgromadzone na rachunku VAT, rozsądnym wydaje się „odmrożenie” maksymalnej kwoty, a więc 23 zł, z rachunku VAT, tym samym wykorzystując jedynie 100 zł (zamiast 123 zł) ze środków najbardziej płynnych, zgromadzonych na rachunku bieżącym przedsiębiorstwa - tym bardziej, że taka decyzja zwalnia przy okazji

${ }^{21}$ Por. art. 453 Kodeksu cywilnego, zdanie pierwsze [w:] Ustawa z dnia 23 kwietnia 1964 r. Kodeks cywilny, tekst jednolity: Dz. U. 2017, poz. 459. 
przedsiębiorstwo z solidarnej odpowiedzialności za VAT. Warto jednak zaznaczyć, że przelew MPP może być zrealizowany tylko pod warunkiem wskazania numeru faktury w komunikacie przelewu. To z kolei wiąże się z wyzwaniami, przed którymi stoją przedsiębiorstwa, które zazwyczaj dokonują płatności zbiorczych, za kilkanaście, kilkadziesiąt lub więcej faktur naraz. MPP wymaga płatności pojedynczych, co zresztą spójnie wpasowuje się w pozostałe elementy systemu zmniejszania luki w VAT (w JPK_VAT przedsiębiorca wykazuje konkretne faktury i odpowiadające im kwoty, w MPP przedsiębiorca opłaca konkretną fakturę przelewem na konkretną kwotę, w STIR administracja skarbowa widzi wyciąg z rachunku i jest w stanie przyporządkować kwotę do faktury). Pojawia się więc presja przedsiębiorców na banki, aby zmniejszyć opłaty za przelewy wskutek zwiększenia liczby transakcji. Banki jednak argumentują, że przelew MPP jest bardziej pracochłonny niż zwykły przelew, więc brak jest przesłanek do obniżenia kosztów. Przy zwiększonym wolumenie przelewów i stałej stawce opłaty za pojedynczy przelew, przedsiębiorstwo ponosi dodatkowy koszt związany z optymalizacją swojej płynności, a więc wykorzystaniem środków z rachunku VAT celem zapłaty kontrahentowi.

Mechanizm Podzielonej Płatności jest zagadnieniem wieloaspektowym i tym bardziej ciekawym, że stanowi nowość w polskiej gospodarce. Bez wątpienia wpływa on na płynność przedsiębiorstwa, i z dużą dozą prawdopodobieństwa można założyć, że w kolejnych latach będzie ewoluował, tak aby zapewnić maksymalną szczelność systemu VAT i minimalizację luki w VAT. Warto obserwować to zjawisko i podejmować próby naukowej analizy poszczególnych mechanizmów, wbudowanych bezpośrednio lub pośrednio w system MPP, takich właśnie jak aspekty zarządzania płynnością.

\section{LITERATURA}

1. Adalsteinsson G., The Liquidity Risk Management Guide. From Policy to Pitfalls, Wiley, Chichester 2014.

2. Aven T., Quantitative Risk Assessment. The Scientific Platform, Cambridge University Press, New York 2011.

3. Bień W., Zarządzanie finansami przedsiębiorstwa, Difin, Warszawa 2011.

4. Bojańczyk M., Finanse przedsiębiorstwa, Oficyna Wydawnicza SGH, Warszawa 2012.

5. Buljevich E.C., Park Y.S., Project Financing and the International Financial Markets, Springer, Berlin 2009.

6. CIMA Study Text. Operational Paper F1. Financial Reporting and Taxation for Exam in 2017, BPP Learning Media, London 2016.

7. Dahmen A., Jacobi P., Bankowa obstuga przedsiębiorstw, CeDeWu, Warszawa 2009.

8. Endovitsky D.A., Popkova E.G. (red.), Management of Changes in Socio-Economic Systems, Springer, Cham 2018.

9. Grzywacz J., Wspótpraca przedsiębiorstwa z bankiem, Difin, Warszawa 2006.

10. Kuchmacz J., VAT $w$ systemie rachunkowości przedsiębiorstwa, Wolters Kluwer, Warszawa 2016.

11. Motylska-Kuźma A., Wieprow J., Decyzje finansowe w przedsiębiorstwie. Problemy i zadania, Difin, Warszawa 2013.

12. Noga A., Teorie przedsiębiorstw, PWE, Warszawa 2010. 
13. Prędkiewicz K., Golej R., Zarządzanie finansami przedsiębiorstwa, Marina, Wrocław 2015.

14. Szelągowska A. (red.), Współczesna bankowość korporacyjna, CeDeWu, Warszawa 2011.

\section{PRAWODAWSTWO}

1. Ustawa z dnia 15 grudnia 2017 r. o zmianie ustawy o podatku od towarów i usług oraz niektórych innych ustaw (Dz.U. z 2018 r., poz. 62).

2. Ustawa z dnia 24 listopada 2017 r. o zmianie niektórych ustaw w celu przeciwdziałania wykorzystywaniu sektora finansowego do wyłudzeń skarbowych (Dz.U. z 2017 r., poz. 2491).

3. Ustawa z dnia 29 sierpnia 1997 r. - Ordynacja podatkowa (tekst jedn. Dz.U. z 2017 r., poz. 201).

4. Ustawa z dnia 23 kwietnia 1964 r. - Kodeks cywilny (tekst jedn. Dz.U. z 2017 r., poz. 459).

5. Druk nr 1864: uzasadnienie rządowego projektu ustawy o zmianie ustawy o podatku od towarów i usług oraz niektórych innych ustaw, Warszawa, 27.09.2017, http://www.sejm. gov.pl/Sejm8.nsf/druk.xsp?nr=1864.

\section{NETOGRAFIA}

1. Luka VAT w Polsce w 2017 r. zmniejszy się o ok. 13 mld zt, 19.10.2017 r., https://www.pwc. $\mathrm{pl} / \mathrm{pl} / \mathrm{media} / 2017 / 2017-10-19$-pwc-luka-vat-2017.html

2. Portal Podatkowy: Jednolity Plik Kontrolny (JPK_VAT): Co to jest JPK_VAT, https://www. finanse.mf.gov.pl/web/wp/pp/jpk/jpk_vat-ogolnie

3. Szacunkowe dane o wykonaniu budżetu państwa za styczeń-grudzień 2017 r., Warszawa, 31.01.2018 r., https://www.mf.gov.pl/documents/764034/5924039/20180131_Szacunkowe_ wykonanie_budzetu_styczen_grudzien_2017+r..pdf

\section{VAT SPLIT PAYMENT MECHANISM AND ITS INFLUENCE ON A COMPANY'S LIQUIDITY}

Split Payment Mechanism (SPM) is one of the most important pillars of the system addressing the VAT gap in Poland. As opposed to other elements of this system, such as Standard Audit File for Taxes (SAF-T) or data reporting within the Clearing House Transactional System, SPM has a significant impact on a company's liquidity. Recording VAT-related funds in special purpose bank accounts usually results in reduced liquidity, with the scenario of total liquidity loss not being excluded either. This is specifically the case of a company whose VAT-related outflows within the SPM precede such inflows, which has been benchmarked against the as-is scenario, as an example. Liquidity indices, as currently found in the literature, seem to be insufficient to assess the SPM influence on a company's liquidity, as there is no distinction between different types of $a$ vista funds recorded in bank accounts. As a result, a modification to existing liquidity indices has been suggested. On the other hand, the analysis of a company's liquidity needs using models estimating optimal cash levels indicates, depending on the assumptions made, an increased need for liquidity or an increased cost of maintaining the existing liquidity levels. What should also be noted is that there are other costs as well that are related to maintaining liquidity in the SPM regime, such as bank fees. Therefore, 
introducing SPM has, as a rule, a negative impact on a company's liquidity, both from the liquidity needs perspective, as well as direct and indirect costs related to SPM.

Keywords: taxes, VAT, corporate banking, liquidity management.

DOI: 10.7862/rz.2018.mmr.29

Tekst ztożono do redakcji: maj $2018 \mathrm{r}$.

Tekst przyjęto do druku: wrzesień 2018 r. 
